\title{
Peões de estôncia e produção familiar na Fronteira sul do Brasil (1845-1865)
}

Luís Augusto Farinattit

Resumo. Por muito tempo, a imagem dos peões de estância no Rio Grande do Sul oitocentista foi a de homens errantes, sem relações familiares importantes e sem acesso a recursos produtivos estáveis. Esse quadro perpetuou-se mesmo em obras cujas matrizes teóricas eram muito diferentes. A proposta deste artigo é problematizar essa questão. As principais fontes empregadas são as qualificações das testemunhas e dos réus presentes nos processos criminais de Alegrete, o maior município da Campanha rio-grandense, entre os anos de 1845 e 1865. Os resultados da pesquisa realizada apontaram que, ao contrário do que se costuma afirmar, para grande parte dos que se assalariavam como peões nas estâncias, esse trabalho era parte de uma estratégia familiar, sendo característico do início da vida produtiva de homens inseridos em famílias de pequenos produtores e de migrantes que buscavam estabelecer-se na região. Na maioria dos casos, esses peões não eram homens sem vínculos familiares relevantes, mas sim jovens que tinham na produção familiar autônoma uma realidade ou um horizonte.

Palavras-chave: Peões. Famílias. Rio Grande do Sul. Século XIX. Pecuária.

\footnotetext{
* Doutor em História Social pela Universidade Federal do Rio de Janeiro (UFRJ). Professor do curso de História do Centro Universitário Franciscano (UNIFRA). E-mail: lafarinatti@gmail.com.
} 
Peões de estância e produção familiar...

\section{Introdução}

Na visão clássica do Rio Grande do Sul oitocentista, os peões eram vistos como "homens soltos". Não teriam vínculos sociais e familiares estáveis, por meio dos quais pudessem ser criadas demandas próprias e estratégias para concretizá-las. Eles seriam recrutados dentre uma população volante de homens vagos. Andariam de estância em estância, empregando-se em um trabalho que não lhes era penoso, mas, ao contrário, era quase um divertimento, em razão de seu gosto pelas correrias e embates com o gado em campo aberto. ${ }^{1}$ Esses sujeitos seguiriam os estancieiros nas guerras em conseqüência do seu sentimento patriótico ou da lealdade para com seus patrões.

Essa imagem romântica foi contestada a partir de fins da década de 1970, quando se apontou que foi a concentração de recursos em poucas mãos que forçou esses homens a empregarem-se nas estâncias. O que fazia com que seguissem seus patrões na guerra seria, justamente, a situação de grande dependência em que se encontravam. Em um importante artigo que desmitificou a idéia da pecuária extensiva como uma "produção sem trabalho", Décio Freitas chegou a afirmar, em uma frase de efeito, que "o gaúcho não era um folgazão, como se lhe apregoa - era um desgraçado, um pobre diabo sem eira nem beira" (FREITAS, 1980, p. 9). Por sua vez, obras da década de 1980 discordaram de Freitas sobre a existência de um "capitalismo pastoril" no Rio Grande do Sul do século XIX. Empregando majoritariamente fontes impressas, alguns autores avançaram no estudo do tema, apontando a inexistência de um mercado de trabalho livre, nos moldes capitalistas, na pecuária, durante a primeira metade do século XIX (CORSETTI, 1983; MAESTRI, 1984; PESAVENTO, 1980). Tais autores apontaram as formas mistas de remuneração dos peões, que envolviam pagamento tanto monetário como em produtos e, em alguns casos, permissão para o arranchamento como agregado. Eles salientaram

Anos 90, Porto Alegre, v. 15, n. 27, p. 359-383, jul. 2008 
a possibilidade de acesso aos meios de subsistência por parte da população, porém, atribuíram esse fenômeno à existência de gado alçado e à dificuldade de vigilância nas estâncias, insistindo no caráter volante dos homens livres pobres.

Essas obras trouxeram uma grande contribuição ao fazerem uma crítica à visão anterior, apontando as relações de dominação que, no discurso tradicional, tinham ficado escondidas sob a capa da "democracia sulina". Contudo, a idéia de que os peões eram "homens soltos", sem maiores vínculos sociais e familiares, continuou firme também nessa historiografia. A diferença era o fato de que, em vez de uma opção decorrente do seu "amor à liberdade", a ausência de vínculo do peão se daria em razão de um sistema de opressão tão poderoso que anularia sua capacidade de construir laços sociais estáveis e significativos. Seu refúgio de resistência encontrava-se mais na mobilidade espacial e no crime do que na criação de estratégias de sobrevivência que envolvessem relações familiares relevantes. Curiosamente, a visão de uma anomia social entre os livres pobres da Campanha perpetuou-se, mesmo em visões antagônicas. $^{2}$

Por sua vez, estudos recentes vêm demonstrando que havia uma combinação de trabalho escravo com trabalho de peões livres nas grandes estâncias (ZARTH, 1997; BELL, 1998; OSÓRIO, 1999; FARINAT'TI, 2003). Além disso, tais obras apontaram a existência de um importante estrato de pequenos produtores em diferentes regiões do Rio Grande do Sul, nos séculos XVIII e XIX. Esses agentes praticavam a lavoura de alimentos e/ou a criação de gado em pequena escala, principalmente por meio do trabalho familiar, ainda que alguns deles também utilizassem mão-de-obra escrava (OSÓRIO, 1999; FOLET'TO, 2002; GARCIA, 2005; FARINATTI, 2007a). A maioria dos autores que demonstraram a existência desses pequenos produtores também sugeriram que ao menos uma parte daqueles que se assalariavam como peões nas estâncias viria exatamente desse grupo. Em vez de homens errantes, uma parte importante dos peões seria formada por pequenos produtores que buscavam complementar 
suas atividades. A sugestão é interessante, porque remete a um universo social muito mais complexo do que a dicotomia "estancieiros x peões". Contudo, esses trabalhos avançaram pouco no que se refere ao embasamento empírico da hipótese de ligação entre peões e pequenos produtores, uma vez que as fontes sobre peões livres são exíguas e suas referências são muito indiretas.

Neste artigo, buscamos contribuir para esse debate, aportando a análise de um novo conjunto de fontes, com ênfase na qualificação de testemunhas e réus em processos criminais em meados do século XIX. Inventários post mortem são utilizados de modo auxiliar. O foco do estudo recai sobre a região da Campanha rio-grandense (fronteira com o Uruguai), em especial o município de Alegrete. Essa zona fora conquistada e ocupada pelos luso-brasileiros nas primeiras décadas do século XIX, transformando-se na principal região e no principal município pecuário da província.

\section{As testemunhas e os réus dos processos criminais}

A verdade é que sabemos bem pouco sobre os homens livres que trabalhavam nas estâncias. As fontes sobre eles não são abundantes. Por serem livres, eles não eram descritos nos inventários, como acontecia com os escravos. Por serem pobres, poucas vezes eram titulares de atos patrimoniais, como escrituras públicas, contratos sobre bens e inventários post mortem. Como eram, na maioria dos casos, analfabetos, não deixaram relatos de próprio punho. Os historiadores argentinos supriram essas deficiências estudando registros contábeis de estâncias e censos sócio-profissionais (FRADKIN; GARAVAGLIA; GELMAN; GONZALES BERNALDO, 1997). O primeiro desses tipos de documentos, apenas agora começa a ser encontrado no Rio Grande do Sul e tem um caráter menos completo do que os registros existentes para as áreas platinas (FARINATTI, 2007a). O segundo, ainda não foi encontrado no estado. 
Mesmo diante dessa conjuntura pouco animadora, em um texto recente e inspirador, Helen Osório enfrentou o desafio de estudar os peões no Rio Grande do Sul, durante os últimos anos do período colonial (OSÓRIO, 2006). Com criatividade, a autora supriu a carência de fontes com a utilização da caracterização sócioprofissional presente na qualificação das testemunhas de processos criminais. Era um procedimento que Hebe Mattos havia utilizado com sucesso para compor a análise das estratégias sociais dos homens livres pobres na província fluminense ao longo do século XIX (MATTOS, 1998). Acreditamos que a aplicação de semelhante técnica aos processos criminais de Alegrete permite desenhar com mais clareza os contornos daquela sociedade, muito mais complexa do que a visão tradicional costuma admitir, e também compreender melhor o lugar ocupado pelos peões naquele contexto.

Naturalmente, a fonte tem seus limites, decorrentes dos critérios que entravam em jogo quando se tratava de ouvir testemunhas em processos criminais. Os segmentos sociais que gozavam de maior respeitabilidade e prestígio na sociedade estudada, tendem a estar sobre-representados. É de se imaginar que os homens adultos, casados, chefes de família e detentores de uma situação econômica estável fossem chamados para testemunhar não apenas quando haviam presenciado o fato, mas também para afiançar uma das versões em jogo ou servir como testemunhas abonatórias. Por sua vez, os sujeitos pertencentes a outros setores da sociedade eram inquiridos apenas quando haviam presenciado os eventos de que tratava o processo ou quando eram moradores das proximidades do local do delito, sabiam do caso "por ouvir dizer" ou podiam garantir qual era "a voz corrente" sobre a situação em questão. Por fim, nos processos analisados, mulheres e escravos somente foram chamados a depor quando haviam efetivamente presenciado as circunstâncias do crime.

Sem esquecer essas restrições, é preciso admitir que as qualificações das testemunhas nos processos criminais são fontes úteis 
para o estudo dos homens livres. O único teste de representatividade que pudemos fazer foi comparar o percentual de homens livres, casados, com mais de 15 anos de idade encontrado no censo de 1858 com o encontrado na amostra de testemunhas. No primeiro caso, eles ficaram em $47 \%{ }^{3}$ No segundo, atingiram 56\%. Ou seja, havia mesmo uma sobre-representação dos homens casados entre as testemunhas. Entretanto, ela não se constituía em uma diferença tão significativa que pudesse prejudicar as análises feitas aqui. Aqueles que testemunharam o crime ou que tinham grande conhecimento dos sujeitos envolvidos precisavam ser chamados. Esse fato agia como um contra-veneno e diminuía os efeitos da elitização das testemunhas, referida anteriormente, o que faz com que a qualificação das testemunhas nos processos criminais seja uma fonte menos elitizada do que os inventários post mortem, por exemplo. Nela, aparecem peões, carpinteiros, pedreiros, jornaleiros - sujeitos que só muito raramente teriam inventários de seus bens realizados após seu falecimento.

Para esta pesquisa, tomamos os processos criminais abertos em Alegrete e depositados no Arquivo Público do Rio Grande do Sul. Eles iniciam em 1845, porém, alguns dizem respeito a crimes acontecidos alguns anos antes. Em razão da existência de um número muito maior de processos criminais a partir de 1850, procuramos equilibrar a amostra trabalhada. Assim, levantamos as testemunhas de todos os processos abertos de 1845 a 1850 e dos processos de um ano a cada três, no período entre 1851 e $1865 .{ }^{4}$ Em vários processos, houve também uma qualificação detalhada do réu, colhida durante seu interrogatório. Incluímos também esses dados. Somando 497 testemunhas e 58 réus, houve um total de 555 pessoas qualificadas nos processos criminais analisados, sendo que, dessas, apenas seis eram escravos. Tomemos o universo das 549 testemunhas e réus livres para ver, agora, o que se pode concluir sobre as ocupações desempenhadas pelos moradores da fronteira e sobre os peões livres, especificamente. 


\section{Vive de ser criador, vive de seu trabalho, vive de ser carpinteiro...}

A Tabela 1 traz a freqüência com que as categorias ocupacionais apareceram dentre as testemunhas e os réus.

TABELA 1 - Testemunhas e réus em processos criminais profissões (Alegrete, 1845-1865)

\begin{tabular}{|l|c|c|c|c|c|c|}
\hline Profissão & $\begin{array}{c}\text { Total de } \\
\text { testemunhas e } \\
\text { réus }\end{array}$ & $\mathbf{\%}$ & $\begin{array}{c}\text { Somente as } \\
\text { testemunhas }\end{array}$ & $\begin{array}{c}\text { Somente os } \\
\text { réus }\end{array}$ & $\%$ \\
\hline Criadores & 129 & 25 & 118 & 26 & 11 & 19 \\
\hline Comerciantes & 74 & 14 & 72 & 16 & 2 & 3 \\
\hline Peões & 67 & 13 & 52 & 11 & 15 & 25 \\
\hline Jornaleiros & 49 & 10 & 39 & 9 & 10 & 17 \\
\hline Artífices & 43 & 8 & 41 & 9 & 2 & 3 \\
\hline Lavradores & 36 & 7 & 31 & 7 & 5 & 9 \\
\hline $\begin{array}{l}\text { Fazendeiros e } \\
\text { stancieiros }\end{array}$ & 20 & 4 & 20 & 4 & - & - \\
\hline $\begin{array}{l}\text { Costureiras e } \\
\text { lavadeiras }\end{array}$ & 14 & 3 & 13 & 3 & 1 & 2 \\
\hline Capatazes & 11 & 2 & 10 & 2 & 1 & 2 \\
\hline Proprietários & 11 & 2 & 11 & 2 & - & - \\
\hline Outros & 59 & 12 & 48 & 11 & 11 & 19 \\
\hline $\begin{array}{l}\text { Total com } \\
\text { referência de } \\
\text { profissão }\end{array}$ & 513 & 100 & 455 & 100 & 58 & 100 \\
\hline $\begin{array}{l}\text { Total sem } \\
\text { referência de } \\
\text { profissão }\end{array}$ & 36 & - & 36 & - & - & - \\
\hline TOTAL GERAL & 549 & - & 491 & - & 58 & - \\
\hline
\end{tabular}

Fonte: Processos criminais. Alegrete. 1845-1865. APRS.

Comparando as duas colunas da Tabela 1, percebe-se que, no caso dos réus, ocorria o contrário do que se passava com as testemunhas: os sujeitos mais frágeis do ponto de vista socioeconômico tendiam a ser pronunciados com mais freqüência em processos 
criminais do que aqueles mais proeminentes. Como vemos, proporcionalmente, os peões e os jornaleiros estão muito mais representados como réus do que como testemunhas. Com os criadores de gado, ocorre o contrário. Mais significativo ainda é o fato de que nenhum fazendeiro ou "proprietário" ocupou a posição de réu nesses processos.

Em outro sentido, os dados da Tabela 1 sugerem uma sociedade bem mais diversificada do que a velha dicotomia entre estancieiros e peões. Os "fazendeiros/estancieiros" representam apenas $4 \%$ dos inquiridos. ${ }^{5}$ Por sua vez, os "criadores", que englobavam pessoas que praticavam a pecuária em escala mais modesta, eram, sim, maioria. Contudo, ambas as categorias somadas chegam apenas a $29 \%$ do conjunto das testemunhas e dos réus. Já os lavradores, apesar da propalada exigüidade agrícola da Campanha, atingiam 7\% do total de testemunhas e réus.

Os comerciantes são a segunda categoria melhor representada na amostra, atrás apenas dos criadores. Como no caso desses, aqueles também apresentavam uma variedade de situações e envergaduras econômicas. Havia desde comerciantes residentes na vila, que eram também importantes prestamistas e faziam negócios de gado, até pequenos vendeiros do meio rural. Quanto à outra categoria, a dos que se designaram como "proprietários", sua caracterização não é evidente. Das onze testemunhas e réus que assim se declararam, encontramos oito em nosso banco de dados. Em pelos menos quatro desses casos, tratavam-se de pessoas que viviam preferencialmente de rendas, normalmente imobiliárias, fossem elas rurais ou urbanas, ainda que também pudessem ser prestamistas. Por sua vez, em um universo de 549 testemunhas e réus, foram identificadas apenas vinte mulheres, todas elas de baixa extração social. Seis declararam viver "do sustento que lhe dá seu marido" ou "de serviços domésticos", enquanto quatorze declararam-se lavadeiras ou costureiras.

O contexto analisado nesta pesquisa tratava-se de uma economia voltada para o mercado interno e assentada na pecuária extensiva, que pôde sustentar uma sociedade mais heterogênea do 
que se costuma supor. Havia nela um número importante de trabalhadores com ofícios especializados (artífices), que exerciam diversas ocupações, tanto na vila quanto nos campos.

Para fazer uma análise por categoria, agregamos informações referentes ao estado civil e à média de idade das testemunhas e dos réus nos processos criminais.

TABELA 2 - Testemunhas e réus em processos criminais relação entre profissão, estado civil e média de idade (Alegrete, 1845-1865)

\begin{tabular}{l|c|c|c|} 
Profissão & Média de idade & Casados/viúvos (\%) & Solteiros (\%) \\
\hline Proprietários & 51 & 90 & 10 \\
\hline Fazendeiros/estancieiros & 49 & 100 & 0 \\
\hline Lavradores & 44 & 78 & 22 \\
\hline Criadores & 38 & 68 & 32 \\
\hline Comerciantes & 36 & 51 & 49 \\
\hline Artífices & 35 & 54 & 46 \\
\hline Costureiras e lavadeiras & 35 & 30 & 70 \\
\hline Jornaleiros & 31 & 59 & 41 \\
\hline Peões & 30 & 37 & 63 \\
\hline Capatazes & 29 & 30 & 70 \\
\hline Outros & 37 & 45 & 55 \\
\hline GERAL & $\mathbf{3 7}$ & $\mathbf{5 6}$ & $\mathbf{4 4}$ \\
\hline
\end{tabular}

Fonte: Processos criminais. Alegrete. 1845-1865. APRS.

Como estamos mapeando, neste artigo, os peões da pecuária, vamos centrar a atenção nas atividades ligadas diretamente ao mundo agrário, que eram as dominantes na fronteira meridional do Brasil. É possível imaginar que as designações "fazendeiro" ou "estancieiro" estivessem referindo-se apenas aos mais abastados criadores de gado, todos proprietários de terra e de grandes estabelecimentos rurais. ${ }^{6}$ Os inclusos nessa categoria eram todos casados e tinham uma média de idade de 49 anos, bastante superior aos 37 da média geral. Os "proprietários" apresentavam características muito 
semelhantes. Também eram todos casados e tinham a mais alta média de idade da amostra, 51 anos. É possível pensar nessas duas categorias como sendo muito próximas. A alta média de idade existente em ambas sugere uma consonância com o fenômeno, conhecido em outras partes do Brasil, em que mesmo os que se dedicavam a outras atividades, como o comércio, tendiam a se tornar proprietários de terra, escravos e, nesse caso, também de gado, atividades de maior prestígio social (FRAGOSO; FLORENTINO, 1993; FARIA; 1998).

Dentre os "criadores", categoria com o maior número de testemunhas e réus, a média de idade baixa para 38 anos, praticamente idêntica à média geral, ao passo que o percentual de casados diminui, embora permaneça alto $(68 \%)$. A categoria dos indivíduos que criavam gado em Alegrete tinha uma variedade muito grande de envergaduras econômicas. Nas décadas estudadas, os grandes criadores (com mais de 2.000 reses) representavam entre 9 e 15\% dos produtores presentes em uma amostra de inventários post mortem, enquanto os pequenos criadores (com menos de 501 reses) eram entre 53 e 72\% (FARINAT'TI, 2007a, p. 90-93). Ainda que detivessem uma parcela minoritária dos rebanhos, esses pequenos criadores eram socialmente muito importantes, e, mesmo dentro dessa categoria, havia uma marcada heterogeneidade.

Dentro deste grupo, estavam filhos de estancieiros que começavam, então, sua atividade própria, como era o caso de José Telles de Oliveira e de Constantino José Lopes, que depuseram no mesmo processo, em 1855: o primeiro tinha 23 anos e já era casado e o segundo, 25 anos e ainda era solteiro. ${ }^{7}$ Também havia pequenos criadores, proprietários das terras em que manejavam seus rebanhos, como Firmiano de Souza Luz, que foi réu em um processo no ano de 1861. Quatro anos antes, havia sido realizado o inventário de sua mulher e, por ele, sabe-se que o casal possuía apenas 1/4 de légua de campo de sua propriedade, cerca de 450 reses, 200 ovelhas e 2 escravas - uma africana, de nome Teresa, de 40 anos, e sua 
filha, Florisbela, com 12 anos de idade. ${ }^{8}$ Havia, ainda, agregados com dezenas ou pouco mais de uma centena de vacuns, alguns cavalos e ovelhas, como Felício José da Silva, morador agregado na Estância Santo Agostinho, que tinha 49 anos e era casado quando depôs, em $1853 .{ }^{9}$

Por sua vez, as testemunhas e os réus incluídos na categoria de "lavradores" podem ser aquelas que aparecem nos inventários post mortem como possuindo instrumentos agrícolas e criando até cerca de 100 reses de gado vacum, não sendo, em boa parte dos casos, proprietários das terras onde viviam. Os estudos de Garavaglia (1999), para Buenos Aires, e de Osório (1999), para o Rio Grande de São Pedro, em fins do período colonial, constataram que aqueles que criavam até 100 reses não tinham como sobreviver exclusivamente da pecuária e nem mesmo eram chamados de "criadores".

Dentre os lavradores, a média de idade (44 anos) e o percentual de casados $(78 \%)$ são superiores aos dos criadores. Os próprios depoimentos das testemunhas e dos réus sugerem que a maioria dos lavradores e parte dos criadores formavam o conjunto daqueles que viviam como agregados nas estâncias, levando a cabo uma produção autônoma, mas modesta, em terras alheias. A média de idade e o percentual de homens casados dentre os criadores seriam semelhantes aos dos lavradores, mas podem ter baixado um pouco em virtude de que, dentre eles, havia filhos de grandes e medianos estancieiros que já criavam gado, embora fossem jovens e, muitas vezes, ainda estivessem solteiros. Vejamos, agora, com mais detalhe, o caso dos peões livres.

\section{Peões livres e produção familiar}

$\mathrm{Na}$ categoria "peões", incluímos os indivíduos que tiveram, nas suas qualificações de profissão, as designações "peão", "campeiro", "peão posteiro" e "vive de seu trabalho de campeiro". Além destes,

Anos 90, Porto Alegre, v. 15, n. 27, p. 359-383, jul. 2008 
Peões de estância e produção familiar...

foram enquadrados também nesse grupo alguns casos de pessoas que declararam "viver de seu trabalho", mas que, pelas circunstâncias do processo, eram evidentemente peões de campo. Ao todo, os peões chegam a 67 pessoas ou 13\% da amostra de testemunhas e réus. Se retomarmos os dados da Tabela 2, veremos que a maioria dos peões era formada por indivíduos solteiros (63\% dos inquiridos) e jovens.

Os $37 \%$ de peões casados formam um percentual bastante inferior aos $56 \%$ do total da amostra. É preciso fazer a ressalva de que esses números correspondem aos casamentos legalizados pelo rito religioso. Provavelmente, o número de uniões consensuais estáveis, porém não formalizadas, não era desprezível. Ainda assim, a comparação da média de idades das testemunhas e dos réus sugere que, dentre os peões, o percentual de homens efetivamente solteiros era maior do que em outras categorias.

A média de idade dos peões é de apenas 30 anos, contra a média de 37 anos da amostra total. Esses números são os menores de toda a amostra, excetuando-se os dos capatazes, cujos percentuais encontram-se distorcidos. Se excetuamos os três casos de capatazes que eram filhos dos proprietários das estâncias onde trabalhavam, a média de idade sobe para 39 anos. Sendo mais específico: 66\% dos peões tinham até 30 anos, enquanto apenas 41\% do total das testemunhas e dos réus ficavam abaixo dessa idade. Essa era uma estrutura que vinha se reiterando desde os tempos coloniais. Em seu estudo sobre os peões nos processos criminais do Rio Grande de São Pedro, entre 1779 e 1834, Helen Osório (1999) apontou que os peões apresentavam um percentual de solteiros de $61 \%$ e uma média de idade de 29 anos, números quase idênticos aos encontrados para Alegrete, em meados do século XIX. Osório verificou que nada menos do que $80 \%$ dos peões estudados por ela tinham até 35 anos. No caso estudado aqui, esse percentual foi de 75\%.

Coloquemos esses números em comparação direta com outros dois grupos rurais: o dos criadores e o dos lavradores. 
GRÁFICO 1 - Estado civil e média de idade das testemunhas e dos réus de processos criminais (Alegrete, 1845-1865)

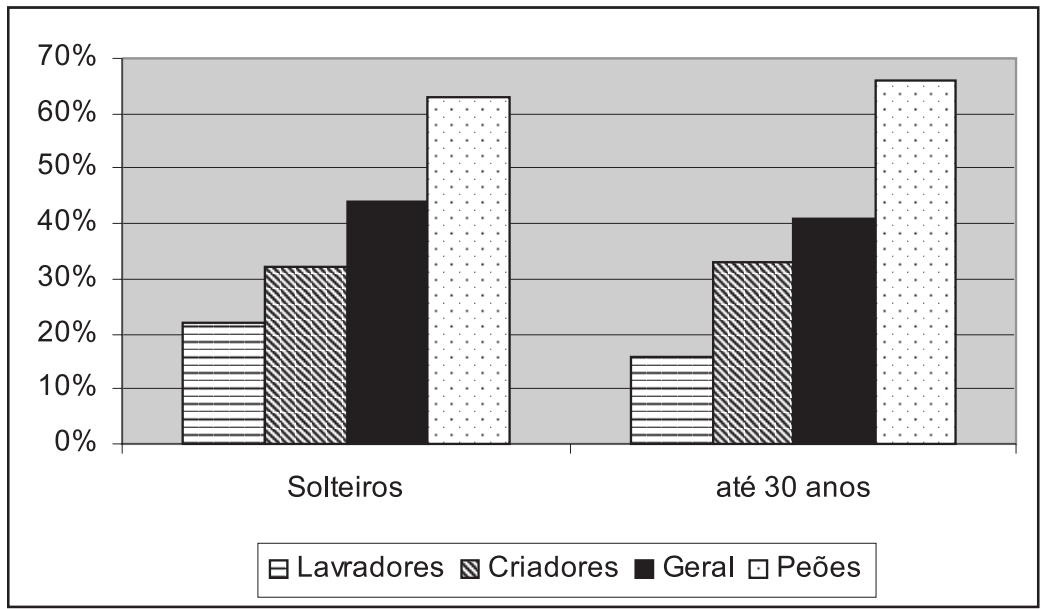

Fonte: Processos criminais. Alegrete. 1845-1865. APRS

Dentre os peões, os percentuais de solteiros e de homens com até 30 anos eram não apenas maiores do que as médias gerais, como também muito maiores do que aqueles alcançados pelos criadores e lavradores. Esses dois grupos, ao contrário, eram formados por uma maioria de indivíduos casados ou viúvos e mais velhos do que os peões. Essa era uma estrutura antiga e espacialmente difundida, que se reproduzia nas terras da Campanha riograndense, em meados do século XIX. Como veremos, a reprodução dessa estrutura estava muito menos ligada a uma suposta anomia social dos peões do que à sua antítese: a elaboração de estratégias de sobrevivência e de acesso a recursos que continuavam sendo relativamente acessíveis (ainda que estivessem deixando de ser, na segunda metade do século XIX), nas quais o ciclo familiar desempenhava um papel relevante.

Em seu trabalho sobre o período colonial, Helen Osório apontou muitas semelhanças entre os dados que encontrou para o 
Rio Grande do Sul, a partir das testemunhas de processos criminais, e as informações de pesquisadores argentinos sobre Buenos Aires, nos censos de 1813 e 1815, e sobre Concórdia, em Entre-Rios, na metade do século XIX. A autora percebeu um "movimento em direção ao envelhecimento, constituição de famílias e 'branqueamento', tendo em uma extremidade os peões, e na outra os criadores e lavradores" (OSÓRIO, 2006, p. 20). Cotejando esses dados com informações de um ofício do governador do Rio Grande, em 1776, a autora demonstrou a vinculação do perfil social dos peões com o ciclo de vida.

Essa não era uma tendência apenas do espaço fronteiriço platino. Investigando os processos criminais da corte de apelação do Rio de Janeiro, Hebe Maria Mattos analisou as designações profissionais presentes nas qualificações de testemunhas de diversas áreas da província fluminense, no século XIX. Os lavradores eram o principal grupo naquela amostra e apresentavam $71 \%$ de seus integrantes como casados ou viúvos. Já os assalariados agrícolas tinham esse percentual em exíguos 5\% (MATTOS, 1998, p. 4044). O estabelecimento como lavrador pressupunha, na maioria dos casos, a constituição de famílias, que acabavam por se tornar a base do trabalho e da organização que permitiam o acesso à produção independente. Por sua vez, as ocupações ligadas ao assalariamento agrícola não-especializado costumavam ter um sentido de temporariedade: eram exercidas até que se conseguisse construir as condições necessárias para o estabelecimento como lavrador.

Hebe Mattos observou que, para parte significativa dos assalariados agrícolas, essa atividade era marcada por um caráter eventual ou temporário. Tratava-se de uma forma de sobreviver e construir laços que permitiriam a inserção social, a formação de famílias e o futuro estabelecimento como produtores independentes. Mattos ressalta que nem sempre essa condição era alcançada, mas que "o sentido social das ocupações só é atingido plenamente quando se percebe o caráter eventual ou transitório com que era encarado 
pelos que as realizavam" (ibid, p. 43). Essa situação somente existia em virtude da possibilidade de acesso ao uso de uma porção de terras, ainda que nem sempre de sua propriedade, e do estabelecimento de uma organização familiar que fornecia o "capital social básico" para a instalação como produtores autônomos no mundo rural.

No Rio Grande do Sul, as coisas se davam de forma semelhante. No caso dos peões que eram migrantes, a maioria segue a tendência geral das testemunhas e dos réus: 58\% vinham de outras áreas da província. Porém, os peões guardam uma especificidade. Nessa categoria, os migrantes vindos do Estado Oriental, do Paraguai ou das províncias argentinas (especialmente Corrientes e Entre Rios) ocupam o segundo lugar, com 28\%, percentual muito superior aos $11 \%$ do total da amostra. Havia, também, libertos, como destaca a conta elaborada pelo brigadeiro Olivério Ortiz, anexada ao inventário de sua esposa. Nele, constam pagamentos por serviço de peão feitos ao "preto forro Manoel". ${ }^{10}$

Ao lado dos peões estavam os filhos de pequenos criadores ou lavradores que complementavam a renda familiar com trabalho assalariado nas estâncias. No inventário do major Antônio Guterres, sua viúva, Ana Guterres, precisou fazer uma pequena prestação de contas dos bens sob sua administração. Nos anos de 1856 e 1857, cobertos por essas contas, o capataz da estância chamava-se Joaquim José Lucas, tendo o mesmo sobrenome do peão Antônio Israel Lucas, que trabalhou por sete meses na estância. ${ }^{11}$ Em 1860, o capataz reapareceu nas fontes pesquisadas como inventariante de sua falecida esposa. Naquele processo, descobrimos que Antônio Israel era filho de Joaquim José e, quando trabalhara para dona Ana Guterres, tinha 18 anos e era solteiro. Antônio Israel tinha, ainda, um irmão e três irmãs, todos já casados. A família possuía um casal de escravos adultos e quatro crianças cativas, além de uma data de matos em São Francisco de Assis, no município de Itaqui, vizinho de Alegrete pelo norte.

Anos 90, Porto Alegre, v. 15, n. 27, p. 359-383, jul. 2008 
Não é difícil imaginar Joaquim José Lucas, sua esposa e o filho solteiro Antônio Israel, vivendo dentro da estância de dona Ana Guterres, em Alegrete, enquanto parte dos outros filhos casados e os escravos praticavam a agricultura do outro lado do rio Ibicuí, na data de matos localizada em São Francisco de Assis. Antônio Israel permaneceu como peão por apenas sete meses. Em parte dos outros 13 meses cobertos pela conta, pode ter se somado aos parentes e escravos nas tarefas de plantação e colheita. A estratégia parece ter sido bem sucedida porque, no ano de 1860, os Lucas haviam comprado uma parte de campo naquela mesma estância e criavam uma ponta de gado, composta de 124 reses xucras e 24 reses mansas. Além disso, o velho Joaquim José continuava trabalhando como capataz para o novo proprietário, o herdeiro Victor Antônio Guterres. ${ }^{12}$

Veja-se que Antônio Israel Lucas, tomado isoladamente, preenchia as características clássicas atribuídas aos peões: era jovem, solteiro e se empregava por salário em uma estância de criação. No entanto, a realização de uma busca mais profunda de seus laços sociais apresenta-o inserido no contexto de uma família que também desenvolvia, em pequena escala, a agricultura e a criação, assentada sobre a diversificação das atividades de seus membros, o acesso à terra, o trabalho familiar e o emprego complementar da mão-deobra escrava. Nesse caso, o acesso à terra deu-se nas áreas florestais acima do rio Ibicuí, onde as possibilidades de apropriação de uma área florestal e de prática da lavoura de roça autônoma permaneciam sendo uma realidade em meados do século XIX (FOLETTTO, 2003). Porém, o mais comum, em Alegrete, talvez fosse o arranchamento como agregado nas terras de outros.

No caso dos Lucas, o trabalho como peão era uma atribuição do membro jovem e solteiro da família. Pelo perfil demográfico apresentado pelos peões nos processos criminais, é possível imaginar que isso ocorresse em muitas outras famílias. Esses jovens podiam voltar para casa e auxiliar nos trabalhos familiares ou podiam 
mesmo ficar o ano inteiro nas estâncias. Contudo, esse trabalho deveria se revestir, para eles, de um sentido de transitoriedade, como apontou Hebe Mattos no caso dos jornaleiros fluminenses (1998). Casar e estabelecerem-se como produtores independentes eram ações que deviam aparecer coligadas em seus horizontes, como sugere o número minoritário de peões casados e o fato de que $66 \%$ deles tinham menos de 30 anos de idade, enquanto lavradores e criadores apresentavam características inversas.

Depois de casados, os peões podiam continuar a assalariar-se nas estâncias, mas pode-se imaginar que, tendo condições, eles preferiam fazê-lo por dia/tarefa ou por apenas alguns meses durante o ano. Dessa forma, poderiam atender a sua produção independente. Assim sendo, o trabalho como peão não parece ter consistido na única alternativa lícita para uns quantos "homens soltos" que vagavam pela fronteira. Em vez disso, em muitos casos, essa ocupação parece ter sido peça de uma estratégia familiar de sobrevivência para os subalternos da Campanha. Em favor dessa hipótese, temos os casos freqüentes de peões que iam com seus familiares contratar-se nas estâncias, e também saiam juntos delas. Em Alegrete, os poucos inventários que trazem contas de salários de peões e que permitem tal tipo de análise contemplam casos como o da estância do Quaraí-Mirim, de propriedade de Joaquim Ferreira Braga, na qual estiveram empregados, por três meses, o peão Mariano "e seu filho"; já Antônio Gonçalves e Feliciano, "genro do mesmo", estiveram contratados na estância de dona Ana Guterres, para as tarefas de marcação e castração, no ano de 1856; por sua vez, o peão Fredo Anhaia esteve na estância da Palma, pertencente ao brigadeiro Olivério José Ortiz, realizando recrutas, juntamente com "dois filhos e um sobrinho" (FARINAT'TI, 2007b, p. 8).

Essa situação é coerente com a estrutura de mão-de-obra encontrada nas grandes estâncias de Alegrete. Nelas, havia um núcleo estável de trabalhadores, composto por escravos campeiros e por peões por mês que ficavam muito tempo na estância (ibid). 
Esses peões submetiam-se a salários baratos, e a maior parte de seus vencimentos era paga em mercadorias. Porém, seu número não era suficiente para que fosse possível formar um sólido mercado de trabalho livre, que permitiria aos estancieiros abandonar o uso do trabalho cativo. Ao contrário, em meados do século XIX, o trabalho de escravos campeiros era ainda estrutural nos maiores estabelecimentos pecuários da Campanha. Havia, também, peões que iam à estância e ficavam por dois ou três meses, em geral nas épocas de maior demanda laboral. Recebiam salários maiores, e uma parte mais significativa dos seus vencimentos era paga em dinheiro. Além de todos esses trabalhadores, ainda havia os peões por dia ou tarefa, que ficavam nas estâncias por alguns dias ou semanas, nos períodos de marcações, castrações, busca de animais evadidos e formação de tropas para as charqueadas. Esses peões eventuais recebiam mais do que todos os outros e quase sempre em dinheiro.

Esses dois últimos casos - dos peões que ficavam apenas alguns meses e dos contratados por dia ou tarefa - eram muito adequados àqueles indivíduos que tinham outras formas de ganhar a vida e precisavam se dedicar a elas em boa parte de seu tempo. Isso é coerente com o fato de que eles recebiam remunerações mais elevadas e pagas majoritariamente em dinheiro. Ainda que nesses casos se pudesse empregar peões totalmente "despossuídos", esses parecem ter estado mais presentes como peões de longo tempo, que precisavam se sujeitar a piores condições de remuneração.

Os migrantes que chegaram a Alegrete no período estudado podiam cumprir trajetórias semelhantes às descritas anteriormente. Como vimos, eles vinham preferencialmente das outras áreas da província e das regiões platinas vizinhas. No caso analisado por Hebe Mattos, o trabalho como peão deve ter funcionado como uma etapa de duração variável, em que os migrantes justavam-se nas estâncias e, a partir de então, iam travando conhecimento do local, buscando criar laços e inserir-se, podendo constituir família. 
Ao mesmo tempo, iam construindo relações de confiança com os estancieiros, que poderiam desembocar na contratação como capataz ou na permissão para se arranchar como agregado, criando alguns animais e fazendo plantações.

\section{Considerações finais}

É certo que nem todos os peões chegaram a instalar-se como pequenos produtores. A enorme concentração de recursos produtivos nas mãos de uma pequena elite agrária não permitia que todos os subalternos pudessem chegar à produção autônoma, nem mesmo em condições precárias, nas primeiras décadas do século XIX. Além disso, um número menor de peões, especialmente os que tivessem habilidades reconhecidas, como a valorizada capacidade para ser domador, podiam preferir continuar a viver do costeio do gado, procurando empregar-se por dia, por poucos meses, ou em tropas, sem nunca buscar tornar-se produtor. Podiam combinar o trabalho como peão com outros trabalhos assalariados, tanto nos campos como nas vilas. Apesar da presença da escravidão, essas outras atividades não-especializadas eram sim um campo de trabalho para os livres pobres, como atesta a presença de jornaleiros formando 10\% das testemunhas e dos réus de processos criminais em Alegrete.

Enfim, parte daquelas pessoas que se assalariavam nas estâncias podia encaixar-se no perfil clássico desenhado para os pobres livres da Campanha: homens que permaneciam solteiros, para quem o trabalho como peão não estava inserido em uma estratégia familiar mais complexa. Porém, eles estavam longe de ser maioria. Como vimos, os indivíduos com mais de 30 anos formavam apenas 34\% do total de peões que tiveram declarado seu estado civil. Eram 22 homens, dos quais 11 eram legalmente casados. Considerando que a existência de uniões conjugais estáveis, mas informais, provavelmente, era bastante difundida nesses estratos, a situação de homens soltos e desenraizados deve ter sido realmente minoritária. 
Peões de estância e produção familiar...

Assim, os dados e os exemplos trabalhados sugerem que, para parte expressiva dos que se assalariavam nas estâncias de Alegrete, ao menos até meados do século XIX, a produção familiar era uma realidade ou um horizonte, como também acontecia com os jornaleiros agrícolas do Rio de Janeiro (MATTOS, 1998, p. 55-72). Algo semelhante ocorria na Campanha de Buenos Aires, no meado do século XIX. Em seu trabalho sobre as estâncias do governador Rosas, Jorge Gelman aponta que a persistência camponesa, em pleno período da grande expansão pecuária argentina, condicionava fortemente a oferta de mão-de-obra nas grandes estâncias (GELMAN, 1999, p. 117).

Possuir um pequeno rebanho e/ou plantações próprias ampliava a margem de autonomia dos subalternos. Por vezes, era possível contar com um ou dois escravos, como no caso dos Lucas, o que conferia pecúlio, mão-de-obra auxiliar e um ganho em prestígio na sociedade escravista. Uma organização familiar estável viabilizava a conquista e a reprodução desses recursos. Mais ainda, ela era a fonte de solidariedade e estratégias compartilhadas que envolviam a combinação de práticas diversificadas, como a produção própria e o assalariamento de alguns de seus integrantes. Esses recursos eram mobilizados pelos grupos sociais menos favorecidos em busca de um nível maior de segurança, em um contexto econômico e institucional extremamente instável. Eles conferiam proteção para os mais velhos, que não precisariam depender apenas do desgastante e perigoso trabalho como peões de estância, posto que deveriam disputar com um largo contingente de homens jovens e fortes.

As duas pedras de toque de toda essa configuração eram a possibilidade do acesso a recursos produtivos e a formação de famílias. Ainda que em escala modesta e em caráter precário, os recursos produtivos continuavam sendo relativamente acessíveis a muitos dos subalternos da Campanha, até meados do século XIX. Não houve a formação de um exército de mão-de-obra constituído 
por uma massa de despossuídos, que responderiam prontamente ao chamado dos estancieiros para o serviço. E isso não ocorria apenas porque uns quantos gaúchos esquivos podiam pegar gado nos campos com relativa facilidade. Mas porque os grupos subalternos estavam reatualizando estratégias de sobrevivência há muito utilizadas no Brasil e no Prata, calcadas no estabelecimento de laços parentais, na diversificação de atividades e na busca por obter e reproduzir a condição de produtor em um contexto familiar.

$\mathrm{O}$ acesso à produção autônoma, no entanto, estava ficando mais difícil, à medida que se avançava no século XIX. As possibilidades de ser pequeno criador de gado ou lavrador, sem ser proprietário de terras, diminuíam década a década. Ao mesmo tempo, o preço das terras elevava-se vertiginosamente (GARCIA, 2005). Esse foi um processo que teve seu início já no meado do oitocentos e deve ter trazido uma fonte de conflitos, não apenas dentre os proprietários e os que desejavam o acesso à terra, mas também internamente dentre este último grupo. A radicalização dessa situação deve ter ocorrido quando da crise da escravidão, nas décadas de 1870 e 1880, e com o início do cercamento dos campos, nesse último decênio. Esse processo de crise nas possibilidades de produção própria para parte significativa dos subalternos e, por sua vez, de construção mais efetiva de um mercado de trabalho livre nos moldes capitalistas, ainda aguarda estudos mais aprofundados por parte dos historiadores.

Ranching workers and family production in the south border of Brazil (18451865)

Abstract. For a long time, the image of the ranching workers in "Rio Grande do Sul" showed wandering men, without important family relationships and without access to stable productive resources. That picture was perpetuated even in works whose proposed theoretical they were very different. The proposal of this article is to problematize that subject. The main used sources are the qualifications of present witness in the criminal processes of Alegrete, the largest municipal district of the "Campanha rio-grandense", between 1845 and 1865. The results of this research

Anos 90, Porto Alegre, v. 15, n. 27, p. 359-383, jul. 2008 


\section{Peões de estância e produção familiar...}

appeared that, for great part of the ranching workers, this work was part of a family strategy. It was characteristic of the beginning of the men's productive life inserted in families of small producers and of migrants that looked for to establish in the area. Most of them was not formed by men without relevant family bonds, but for youths that had in the autonomous family production a reality or a project.

Keywords: Ranching Workers. Families. Rio Grande do Sul. XIX Century. Ranching System.

\section{Notas}

${ }^{1}$ Ver, dentre outros, VIANA, 1974, GOULART, 1984 e CESAR, 1979.

${ }^{2}$ Nesse sentido, é impossível deixar de notar a semelhança desse contexto historiográfico com o que aconteceu com a análise da escravidão brasileira, algumas décadas antes. Uma avaliação profunda e erudita sobre o tema está em SLENES, 1999, p. 28-68. 3 "Mappa statístico da população da província classificada por idades, sexos, estados e condições com o resumo do total de livres, libertos e escravos". In: FUNDAÇÃODE ECONOMIA E ESTATÍSTICA. De Província de São Pedro a Estado do RS, 1981, p. 69. ${ }^{4}$ Excluímos alguns processos por se tratarem de crimes ocorridos em Uruguaiana e Santana do Livramento, que estavam sob jurisdição de Alegrete.

${ }^{5}$ Dentre os depoentes, dezesseis foram designados como "fazendeiros" e quatro, como "estancieiros". Por outros documentos, como inventários post mortem e escrituras públicas, foi possível investigar o perfil sócio-econômico de todos os depoentes, os quais parecem ser muito semelhantes. Como já foi referido, na documentação pesquisada encontrei os termos "fazenda" e "estância" utilizados para designar as mesmas unidades produtivas. Algumas vezes, isso ocorria inclusive nos mesmos documentos.

${ }^{6}$ Como era o caso do tenente-coronel Apolinário de Souza Trindade ou de Francisco Martins da Cruz Jobim, presentes entre as testemunhas pesquisadas.

${ }^{7}$ Processos criminais. Alegrete, M. 80, N. 2807, A. 1855. APRS. Foi possível conhecer o perfil social dos sujeitos citados, porque, em trabalho anterior, elaborei um banco de dados nominal sobre Alegrete, entre 1830 e 1870, com base em documentos diversos.

${ }^{8}$ Processos criminais. Alegrete, M. 84, N. 2925, A. 1861. APRS. Inventários post mortem. Alegrete. Cartório de Órfãos e Ausentes, M. 12, N. 168, A. 1857.

${ }^{9}$ Processos criminais. Alegrete, M. 79, N. 2776, A. 1853. APRS.

${ }^{10}$ Inventários post mortem. Alegrete. Cartório de Órfãos e Ausentes: M. 08, N. 111, A. 1852. APRS.

Anos 90, Porto Alegre, v. 15, n. 27, p. 359-383, jul. 2008 
${ }^{11}$ Inventários post mortem. Alegrete. Cartório de Órfãos e Ausentes. N . 117, A. 1853. APRS.

${ }^{12}$ Inventários post mortem. Alegrete. Cartório de Órfãos e Ausentes: M. 08, N. 117, A. 1853. Inventários post mortem. Alegrete. Cartório do Cível e Crime: M. 02, N. 45, A. 1860. APRS.

\section{Referências}

BELL, Stephen. Campanha Gaúcha: a brazilian ranching sistem, 1850-1928. Stanford: Stanford University Press, 1998.

CESAR, Guilhermino. Ocupação e diferenciação do espaço. In: DACANAL, José Hildebrando; GONZAGA, Sérgius (orgs.). RS: economia e politica. Porto Alegre: Mercado Aberto, 1979, PP. 07-27.

CORSETTI, Berenice. Estudo da charqueada escravista gaúcha no século XIX. Niterói, 1983. 343f. Dissertação (Mestrado em História) - Programa de Pós-Graduação em História, Universidade Federal Fluminense.

FARIA, Sheila de Castro. A Colonia em Movimento: fortuna e família no cotidiano colonial. Rio de Janeiro: Nova Fronteira, 1998.

FARINATTI, Luís Augusto E. Um campo de possibilidades: notas sobre as formas de mão-de-obra na pecuária (Rio Grande do Sul - século XIX). História - Unisinos, São Leopoldo, v. 8, p. 253-276, ago-dez 2003.

. Confins Meridionais: famílias de elite e sociedade agrária na fronteira sul do Brasil (1825-1865). Rio de Janeiro, 2007. 421 f. Tese (Doutorado em História) - Programa de Pós-Graduação em História, Universidade Federal do Rio de Janeiro.

. Trabalhadores da pecuária: mão-de-obra livre e escrava nas estâncias da fronteira meridional do Brasil (1825-1865). I Congresso Latinoamericano de Historia Económica. Montevidéu, 2007. CD-ROM.

FOLETTO, Arlene Guimarães. Dos campos junto ao Uruguai aos matos de Cima da Serra: paisagem agrária e estrutura produtiva em São Patrício de Itaqui (1850-1889). Porto Alegre, 2003. 184 f.Dissertação (Mestrado em História) - Programa de PósGraduação em História, Universidade Federal do Rio Grande do Sul.

FRADKIN, Raúl; GARAVAGLIA, Juan Carlos; GELMAN, Jorge; GONZÁLEZ BERNALDO, Pilar. Cambios y permanencias: Buenos Aires en la primera mitad del siglo XIX. In: Anuário I.E.H.S. "Prof. Juan Carlos Grosso", n. 12. Tandil: UNCPBA, 1997.

Anos 90, Porto Alegre, v. 15, n. 27, p. 359-383, jul. 2008 


\section{Peões de estância e produção familiar...}

FRAGOSO, João L.; FLORENTINO, Manolo. O arcaísmo como projeto. Rio de Janeiro: Diadorim, 1993.

FREITAS, Décio. O mito da produção sem trabalho. In: DACANAL, José Hildebrando; GONZAGA, Sérgius (orgs.). RS: economia e política. Porto Alegre: Mercado Aberto, 1979, pp. 07-24.

GARAVAGAGLIA, Juan Carlos. Pastores y labradores de Buenos Aires: una historia agraria de la campaña bonaerense (1700-1830). Buenos Aires: Edicioines de la Flor, 1999.

GARCIA, Graciela. O domínio da terra: conflitos e estrutura agrária na Campanha riograndense oitocentista. Porto Alegre, 2005. 191 f. Dissertação (Mestrado em História) Programa de Pós-Graduação em História, Universidade Federal do Rio Grande do Sul.

GELMAN, Jorge. Las condiciones del crecimiento estanciero en el Buenos Aires de la primera mitad del siglo XIX: trabajo, salarios y conflitos en las estancias de Rosas. In: GELMAN, Jorge; GARAVAGLIA, Juan Carlos; ZEBERIO, Blanca (org.). Expansión capitalista y transformaciones regionales: relaciones sociales y empresas agrarias en la Argentina del siglo XIX. Buenos Aires: Editorial La Colmena, 1999.

GOULART, Jorge Salis. A formação do Rio Grande do Sul. 4. ed. Porto Alegre: Martins Livreiro; Caxias do Sul: EDUCS, 1984.

MAESTRI, Mario. O escravo no Rio Grande do Sul: a charqueada e a gênese do escravismo gaúcho. Porto Alegre: EST, 1984.

. O cativo e a fazenda pastoril sul-rio-grandense. In: - Deus é grande, o mato é maior: trabalho e resistência escrava no Rio Grande do Sul. Passo Fundo: Editora da UPF, 2002.

MATTOS, Hebe Maria. Das cores do silêncio: os significados da liberdade no sudeste escravista (Brasil, século XIX). Rio de Janeiro: Nova Fronteira, 1998.

OSÓRIO, Helen. Estancieiros, lavradores e comerciantes na constituição da estremadura portuguesa na América: Rio Grande de São Pedro, 1737-1822. Niterói, 1999. 315 f. Tese (Doutorado em História) - Programa de Pós-Graduação em História, Universidade Federal Fluminense.

. Trabalhadores da pecuária: peões e gaudérios na fronteira do Império Português. XX Jornada de Historia Económica. Buenos Aires, 2006.

PESAVENTO, Sandra. República Velha gaúcha: frigoríficos, charqueadas, criadores. Porto Alegre: Movimento/IEL, 1980.

SLENES, Robert. Na Senzala uma flor: esperanças e recordações na formação da família escrava, Brasil, sudeste, século XIX, 1999.

VIANNA, Oliveira. Populações meridionais do Brasil-v. 1. Belo Horizonte: Itatiaia, Niterói: EDUFF, 1987.

Anos 90, Porto Alegre, v. 15, n. 27, p. 359-383, jul. 2008 


\section{Luís Augusto Farinatti}

- Populações meridionais do Brasil - v. 2: o campeador rio-grandense. Rio de Janeiro: Paz e Terra, 1974.

ZARTH, Paulo Afonso. História agrária do planalto gaúcho (1850-1920). Ijuí: Editora da Unijuí, 1997.

Recebido em 25/01/2008. 
